\title{
POLSKIE PODRECZNIKI DO NAUCZANIA DYSCYPLIN PATROLOGICZNYCH
}

Scharakteryzowanie wszystkich polskich podręczników, nawet w krótkich słowach, jest przedsięwzięciem karkołomnym i obawiam się, że musiałoby skończyć się uogólnieniami i frazesami, a nadto byłoby nudną wyliczanką zacnych przymiotów tych dzieł. Moja trudność polega też na tym, że sam jestem autorem małego podręcznika teologii patrystycznej, a przecież powszechnie wiadomo, że każda pliszka przede wszystkim swój ogon chwali. Jakoś jednak postaram się książki te przedstawić. Zaznaczam, że moje wywody będą dotyczyć tylko i rygorystycznie podręczników, choć trudno odmówić podręcznikowego charakteru również wielu antologiom. Pominę też thumaczenia $z$ innych języków.

Pierwszym podręcznikiem polskim w pełnym tego słowa znaczeniu jest księdza Józefa Szpaderskiego, kanonika warszawskiego, dzieło w dwóch tomach pod tytułem Patrologia (Ojcoznawstwo) albo nauka o Ojcach Kościoła Katolickiego i znakomitych pisarzach kościelnych, wydane w 1879 r. w Krakowie nakładem A. Koziańskiego, który naonczas dzierżawił drukarnię Franciszka Pobudkiewicza, co podano dla wiadomości potomnych, jak również i parę innych potrzebnych dla ogólnej kultury szczegółów: że książkę rozprowadzała księgarnia Gebethnera i Sp., że „nie zawiera w sobie nic przeciwnego zasadom katolickiego Kościoła” i że na książkę zaabonowały się 53 osoby (ich nazwiska wypisano na początku tomu drugiego). Pierwszy tom miał 310 stron in octavo, drugi - 377, choć zecer niestarannie po stronie 365 dał 466 itd. Rzeczą interesującą jest poświęcenie przez autora około 100 stron na - jak on to nazywa - „patrologija ogółowa”, czyli uwagi o całości spuścizny Ojców, o ich znaczeniu, o potrzebie studiowania, powadze, o przekazie tekstu, o językach, historii i zarzutach Ojcom stawianym. Dalej następuje dział II, czyli „Ojcoznawstwo szczegółowe”; do końca I tomu pisze o pierwszych trzech wiekach, w tomie II - o „drugich trzech wiekach Kościoła”, oraz o Ojcach aż do XIII wieku; kończy na Tomaszu z Akwinu. O każdym z Ojców pisze życiorys i księgorys, wymieniając również pisarzy, których dzieła zaginęły, bo któż dziś wymienia niejakiego Sexta, który w II wieku 
napisał Księge o zmartwychwstaniu lub Arabiana, który stworzył „dziełko jakieś”? Zacny Autor sam przedstawia swą pracę w uroczym „Przedsłowiu”: ,...przynoszę młodzieży duchownej katolickiej w mowie ojczystej dzieło naukowe, w szkole po obcemu Patrologia zwane; my to po polsku nazwaliśmy Ojcoznawstwem, gdy obejmuje nie tylko życio- i księgorysy Ojców i pisarzy kościelnych, lecz umiejętności oceniania i zużytkowania tego drugiego Objawienia źródła, tradycji, jaka się w dziełach Ojców i pisarzy kościelnych skrystalizowała niejako i weszła do skarbca Kościoła. Przyjmą je kapłani, to dobrze; przyjmą szkoły, to jeszcze lepiej, a przynajmniej brakiem dzieł wymawiać się nie będą; nie przyjmą lub cisną kamieniem, to niejeden świecki człowiek może zapragnie poznać i poczerpnąć coś z tych świętych i zakrytych dotychczas dla profanów skarbów wieku mądrości. Może więc marnie czasu i atłasu się nie strada" (s. 4).

Ksiądz Kanonik Szpaderski wydał również kilka lat wcześniej podręcznik O zasadach wymowy mianowicie kaznodziejskiej (Odczyty akademickie), Kraków 1870, Czytelnia Ludowa, t. 1: Zasady wymowy, ss. XVI + 333, t. 2: Historya wymowy, ss. 514. W tej zaś Historyi poświęcił 120 stron Ojcom Kościoła, w tym Hermiaszowi, co ojciec Bober opatrzył zniesmaczoną uwagą na luźnej karteczce: ,jego szmirę prawie w całości przytoczył”.

Następnym w kolejności spośród tych, którzy „czasu ni atłasu” na Ojców nie szczędzili, był Władysław Chotkowski, autor książki Patrologia czyli Historia Literatury Chrześcijańskiej według wykładów, wydanej przez Jana Fijałka w Krakowie w 1884 roku. Nie dotarłem do tych wykładów, przejdźmy więc do następnej książki, tym razem wydanej w Warszawie.

Jest to książka ks. Rocha Filochowskiego: Ojcowie i Pisarze Kościoła, z drukarni Stanisława Niemiery na Placu Wareckim 4, AD 1893. Дозволено Цензурою, stron 190 in sexto decimo. Książeczka to mała i bardzo wybiórcza. Mamy więc w niej Ireneusza, Pantajnosa (zwanego Pantenem), o którym przytacza nieprawdopodobnie dużo wiadomości, na przykład tę, że „w Indyach znalazł księgę Ewangelii świętego Mateusza, którą tam był zaniósł święty Apostol, opowiadając najpierwszy naukę Chrystusa w tych odległych krajach" (s. 36), potem Klemensa i Orygenesa, któremu poświęca aż 18 stron (48-66). Z wyraźną sympatią przypuszcza też, ,iż przepisywacze wcisnęli przez złość błędy do dzieł Orygenesa, a w takim razie nie byłby winien temu" (s. 66). Z Kapadocczyków opisuje tylko Grzegorza z Nyssy, nie ma Atanazego, jest za to Epifaniusz, nie ma Ambrożego, Augustyna ani Hieronima, ale jest na przykład Fulgencjusz, Ildefons z Toledo czy Beda Wielebny. Kryterium wyboru autor nie podał, jego program można by więc nazwać - językiem reformy oświatowej - programem autorskim. Ksiądz Roch rzetelnie przytacza jednak źródła swojej wiedzy. Jest to czasem Euzebiusz, czasem Hieronim, a przede wszystkim Martyrologium Romanum oraz Żywoty Świętych Pańskich pióra ojca Skargi, Encyklopedia Powszechna, Encyklopedia Kościelna, a także obie 
cytowane wyżej książki kanonika Szpaderskiego. Jako że autor na końcu prosi czytających o Zdrowaś Maryja, pomyślmy o nim z sympatią.

Podręcznikiem polskim, choć nie po polsku napisanym, jest Patrologiae compedium scholis accommodatum Andrzeja Retke, profesora homiletyki i patrologii w Rzymsko-Katolickiej Akademii Petersburskiej, wydane w Warszawie w 1889 roku'; zawiera on 310 stron in octavo. Podaje krótko bibliografię i ważniejsze zbiory pism Ojców. Dowiadujemy się z niego, że nie słyszano w Petersburgu o dwujęzycznej Patrologii Greckiej Migne'a, jedynie o jej poprzednim wydaniu po łacinie w osiemdziesięciu i jednym tomie. Omawia zwięźle wszystkich Ojców i pisarzy aż do Bernarda z Clairvaux. Podaje ich życiorysy i charakteryzuje dzieła, nie przedstawiając jednak ich nauki. Mógł więc czytelnik tego podręcznika dowiedzieć się, co kto napisał, ale dalej nie wiedział o czym.

„Nakładem Akademickiej Spółdzielni Wydawniczej z odpowiedzialnością udziałowców w Warszawie" w 1947 r. ukazały się Prolegomena patrologiczne księdza dra Jana Czuja. Jest to dość porządnie oprawiony, paskudnie powielony, niestaranny maszynopis. W treści zaś jest najpierw streszczeniem, a potem tłumaczeniem $\mathrm{z}$ opuszczeniami pierwszego tomu Historii literatury starochrześcijańskiej Ottona Bardenhewera z 1913 r. (ss. 1979). Przejdźmy zatem do dwukrotnie wydawanego podręcznika tegoż ks. Jana Czuja o prostym tytule Patrologia (Poznań 1953, ss. 218 i 1954, ss. 312). Wstęp do obydwu tych wydań jest lekko skróconą wersją powyższych Prolegomena. Pozostałe części też wykazują zależności od innych autorów. Sylwetki Ojców przedstawione są rzetelnie, oczywiście jak na ówczesny stan wiedzy, krótko scharakteryzowane ich dzieła, prawie nic jednak nie ma na temat ich poglądów filozoficznych i teologicznych. Cenna jest też bibliografia wskazująca miejsca wydania dzieł Ojców i ich polskich tłumaczeń. Różnic między wydaniami jest niewiele: trochę uzupełnień bibliograficznych, kilka stron poświęconych herezjom czwartego wieku i sześć sylwetek późnych Ojców łacińskich. Znaczna różnica w ilości stron została spowodowana pomniejszeniem formatu książki i równoczesnym powiększeniem czcionki. A jeśli jesteśmy już przy wielkościach, to warto też zaznaczyć, że nakład wzrósł dwukrotnie, z 5 na 10 tysięcy, a cena została obniżona z 40 na 32 zł.

Zdecydowanie nowocześniejszym podręcznikiem była księdza Szczepana Pieszczocha Patrologia. Wprowadzenie w studium Ojców Kościoła, wydana przez Księgarnię św. Wojciecha w Poznaniu w 1964 roku (ss. 268). Standardowe ,prolegomena” uzupełnione zostały o rozdział poświęcony teologicznej działalności Ojców, zrezygnował natomiast Autor, co z przyjemnością podkreślam, z powszechnych wcześniej osądów na temat tego, kto na miano Ojca Kościoła zasługuje, a kto nie. Przy omawianiu poszczególnych Ojców zajmuje

\footnotetext{
${ }^{1}$ Omówienie tej książki dał o. Andrzej Bober w VoxP 3(1983) z. 4, 257-265.
} 
się również ich poglądami, a co najważniejsze, jako pierwszy podaje wypisy z dzieł Ojców. Czasem co prawda są one tak krótkie, jednozdaniowe, że sprawiają wrażenie „podpórek” dla ahistorycznych twierdzeń teologii dogmatycznej, ale są. Książkę zamyka rozdział o teologii późniejszej, zwracający uwagę na wybitnych teologów po Hansa Künga i Josepha Ratzingera, co świadczy o rozległości zainteresowań teologicznych czcigodnego Autora. Po raz pierwszy też podano poważną bibliografię (187-222) i appendiksy na temat współczesnej patrologii.

To, co podkreśliłem jako największą wartość tego podręcznika, zostało jeszcze poprawione w kolejnych jego wydaniach: Patrologia, wydanie nowe, t. 1: Działalność Ojców, ss. 284 (w tym w opracowaniu ks. S. Longosza polskojęzyczna bibliografia 1900-1993 i wykaz polskich patrystycznych serii wydawniczych, ss. 201-280 + I-XXIV), t. 2: Ojcowie mówia, ss. 262 (antologia), Gniezno 1994, Gaudentinum, oraz Patrologia w jednym tomie, wydanie III uzupełnione, Gniezno 1998, ss. 414 (bez bibliografii, ale z poszerzonym wykazem polskich patrystycznych serii wydawniczych w opracowaniu ks. S. Longosza, cytaty z dzieł Ojców znacznie obszerniejsze i opatrzone indeksem pojęć teologicznych).

Inny charakter posiada podręcznik, a właściwie skrypt, ojca Jana-Marii Szymusiaka SJ (Patrologia. Zagadnienia wybrane, Lublin 1971, KUL, ss. 196 in quatro). Dzieli się on na „Wiadomości wstępne” oraz „Zagadnienia wybrane". W pierwszej części znaleźć można te same ramowo wiadomości, co w innych „prolegomenach”, natomiast w głównej części zajmuje się przede wszystkim teologią Ojców. Najpierw pisze o egzegezie i liturgii, gdzie wykorzystuje te same materiały, które przygotował do Słownika Wczesnochrześcijańskiego Piśmiennictwa oraz o Bożym planie zbawienia w ujęciu wybranych Ojców (Klemens Aleksandryjski, Orygenes, Atanazy, Hilary z Poitiers, Kapadocczycy i Jan Damasceński). Poświęca także kilka stron literaturze polemicznej i monastycznej. Całość kończy trzydziestostronicowa bibliografia (ss. 163192) wskazująca miejsca wydań dzieł Ojców i ich polskie tłumaczenia. W zakończeniu na temat patrologii w Polsce o. Szymusiak napisał: „Mimo wielu jeszcze przeszkód, materialnych i moralnych, jak trudności w publikowaniu prac lub brak zrozumienia dla pracy naukowej w tej dziedzinie ze strony kompetentnych władz, zapowiada się szczęśliwa przyszłość, która oglądać będzie owoce wysiłków młodszych pokoleń badaczy” (s. 161). W „proroctwie” tym bezwzględną wartość zachowuje uwaga o „braku zrozumienia dla pracy naukowej w tej dziedzinie ze strony kompetentnych władz".

Bestsellerem wśród podręczników patrologii jest książka ks. Wojciecha Kani: Świadkowie Tradycji. Rys patrystyczny, Tarnów, cztery wydania w latach 1982-1998. Jest to zwięzła książeczka (ss. 180 in octavo) przedstawiająca z wielką miłością sylwetki Ojców i zarys ich myśli. Nowością w stosunku do poprzednich opracowań jest $w$ tym podręczniku zwrócenie uwagi na poezję 
Ojców. Pięknie przetłumaczone hymny i poematy są niewątpliwie ozdobą tej książeczki.

Następnym w kolejności jest mój podręcznik teologii patrystycznej wydany w roku 1991 w Wydawnictwie - jeszcze - „Maszachaba” pod tytułem $B y$ nie milczeć o Bogu (ss. 220 w zeszytowym formacie). Tytuł ten wziąłem od św. Augustyna, który - jak pisze - dzieła o Trójcy Świętej nie stworzył dlatego, iżby miał coś mądrego o Bogu do powiedzenia, ale dlatego, że o Bogu nie można milczeć. Defekty tej książki są liczne i powszechnie znane: zbyt zwarta, trudna, miejscami wręcz nieczytelna, zrozumiała tylko dla tych studentów, którzy słuchali moich wykładów. Krótko mówiąc, jak Stromata Klemensa Aleksandryjskiego, które nie służą temu, by się z nich czegoś dowiedzieć, ale by przypomnieć sobie, co profesor mówit. Zamiast porządnych „Prolegomena”, które przecież mogłem choćby odpisać z książki ks. J. Czuja, dałem przydługi artykuł o teologii Logosu u Filona Aleksandryjskiego, bardziej dla hobbystów niż normalnych studentów teologii. Ponadto, mimo dumnego tytułu, że to niby zarys teologii patrystycznej, książka przedstawia jedynie teologię trynitarną i chrystologię, pomijając sprawy znacznie bardziej obchodzące współczesnego człowieka, jak teologia małżeństwa, rodziny, kwestie społeczne, stosunek do pracy, a nawet miłość bliźniego i koncepcje Kościoła. Ze wstydem też muszę przyznać, że zbyt mało miejsca poświęciłem eschatologii, a przecież właśnie oczekiwanie powtórnego przyjścia Chrystusa było siłą napędową starożytnego chrześcijaństwa. Nie poruszam również teologii inicjacji chrześcijańskiej, a o katechumenach piszę jedynie tyle, że za Septymiusza Sewera byli prześladowani. A co powiedzieć o dziewictwie i życiu monastycznym? - na podstawie mojego podręcznika - prawie nic. Wyszło też - jak szydło z worka - że bardziej lubię teologię wschodnią niż zachodnią, co może być moim prywatnym upodobaniem, w podręczniku jednak powinno być bardziej zakamuflowane. Aż dziw bierze, że ks. Edward Staniek pozytywnie zaopiniował ją do druku. $\mathrm{Z}$ tych i innych jeszcze powodów, które $\mathrm{z}$ łatwością wyliczy każdy, kto próbował tę książkę wziąć do ręki, nie poleca się jej lektury. Nie spowoduje to plajty wydawnictwa, gdyż nakład - na szczęście - dawno już się wyczerpał. Pozostaje mi tylko mieć nadzieję, że szkodliwość społeczna tej książki nie była zbyt wielka, gdyż wydano jej tylko 9950 egzemplarzy. W przygotowywanym obecnie nowym podręczniku spróbuję się poprawić.

Znacznie bardziej nadającym się do użytku podręcznikiem wprowadzającym w patrologię jest Wprowadzenie do Ojców Kościoła ks. Antoniego Żurka, wydane w 1993 r. nakładem Instytutu Teologicznego Księży Misjonarzy w Krakowie. Jest to książeczka mała, gdyż posiada tylko 160 stron, za to dobrze zagospodarowanych. Przedstawia zwięźle wszystkich ważniejszych Ojców, daje zarys ich poglądów teologicznych i duchowości. Autor wykazuje w nim nastawienie pragmatyczne i daje do zrozumienia, że nie spodziewa się 
po swoich studentach, iż nauczą się więcej w ramach podstawowego kursu patrologii. A życie przyznaje mu rację.

Ostatnim polskim podręcznikiem jest Patrologia ks. Franciszka Drączkowskiego, wydana w 1998 r. nakładem Wydawnictwa Diecezji Pelplińskiej „Bernardinum”. Księga ta objętością plasuje się bliżej Altanera niż Żurka, których to książki uznał Autor za skrajne i postanowił między nimi się zmieścić. Co obiecał, to uczynił i podręcznik ma 445 stron dziełowego formatu B5 dowodząc, że „optymizm dydaktyczny” księdza Drączkowskiego jest wyższy niż księdza Żurka. Wydawnictwo rzetelnie też podało, że przekłada się to na 20,3 arkusza wydawniczego i 28 arkuszy drukarskich. Łatwo z tego wyliczyć, że drukowano szesnastkami. To imponujące dzieło obejmuje okres do Izydora z Sewilli i Jana Damasceńskiego, co świadczy o przywiązaniu Autora do tradycji tak właśnie określającej okres patrystyczny. Największą zaletą tego podręcznika jest zamieszczenie wielu tekstów pochodzących z dzieł Ojców ilustrujących ich poglądy teologiczne. Oprócz tego znaleźć tam można także streszczenie głównych aspektów ich myśli. Ogólnie biorąc, jest w tej książce wszystko, co potrzeba: podstawowa bibliografia (ss. 15-18), indeksy (ss. 429-439), mapy (niektóre nawet kilkakrotnie powielane), omówienia dzieł. Doskonałe jednak jest tylko to, co stworzył Pan Bóg i pewnie dlatego natrafić można na przykład na taki lapsus, jak przypisanie Orygenesowi głoszenia zbawienia demonów. Niewątpliwie jednak jest to podręcznik poważny i będzie stanowił równie poważne wyzwanie dla każdego, kto zechce napisać nowy.

Pozwolę sobie jeszcze powiedzieć kilka słów ogólniejszej natury na temat tych wszystkich podręczników. Łatwo zauważyć, że wszystkie są napisane przez księży, zasadniczo wykładowców patrologii w seminariach duchownych. Formacja, wykształcenie i zawód wykonywany dają o sobie znać. Podręczniki są podporządkowane nauczaniu teologii, mniej życiu. Mogą w najlepszym razie pomóc w uporządkowaniu pojęć teologicznych i w ich zrozumieniu, natomiast niewiele w nich odniesień do współczesnego życia Kościoła i problemów jego członków. Chętnie cytujemy w nich zdania mówiące o skarbach ukrytych w pismach Ojców, o ich mądrości życiowej, o przykładzie ich otwartości, o znaczeniu ich dzieła inkulturacji chrześcijaństwa. Pokazujemy natomiast przede wszystkim hermetyczność języka, świat pojęć nieprzystawalny do naszej kultury, spory starożytne bez większego znaczenia dla współczesności, czy niektóre ekstremalne dziwactwa. Następuje ciekawe zjawisko: pracownicy naukowi Uniwersytetu Gdańskiego (J. Iluk), WSP w Bydgoszczy (J. Jundziłł i jego liczny zespół współpracowników), UW z panią Ewą Wipszycką i wielu innych, wyciągają skarby z pism Ojców dotąd nieodkryte: o małżeństwie, rodzinie, handlu, pracy, żeglowaniu, wojowaniu, oszczędzaniu i skąpieniu, my zaś, klerykalni teolodzy, przepisujemy jeden po drugim te same życiorysy i dogmatyczne lub umoralniające teksty. Bynajmniej nie płynie to z niewiedzy, ale raczej z jakichś nie do końca uświadomionych założeń. A może nasza teologia nie 
potrafi objąć życia z jego wszystkimi problemami? Może wygodniej nam chować się w starej teologii systematycznej, która ani z życiem nie ma wiele wspólnego, ani z Ojcami Kościoła, a my ich w ten system wtłaczamy? Dość to smutne konkluzje, zdaję sobie sprawę, że dyskusyjne i wcale nie trzeba się ze mną zgadzać. Oczywistą jest rzeczą, że nasz polski dorobek w dziedzinie podręczników patrologii jest już znaczący i nie ma się czego wstydzić. Gdybyśmy jednak na tym poprzestali, znowu wyprzedziłoby nas życie.

\section{MANUALI POLACCHI DI PATROLOGIA}

(Riassunto)

Sono dodici i manuali, cominciando dalla Patrologia di J. Szpaderski del 1879. Autori degli altri sono: W. Chotkowski (1884), R. Filochowski (1893), A. Retke (1889), J. Czuj (1947, 1953, 1954), Sz. Pieszczoch (1964, 1994, 1998), J.M. Szymusiak (1971), W. Kania (1982, 1998), H. Pietras (1991), A. Żurek (1993), F. Drączkowski (1998). L'articolo riporta le principali notizie bibliografiche con qualche cenno al carattere proprio di ciascun manuale. Va osservato che tutti sono stati scritti dai preti, professori di patrologia nei seminari, espongono il materiale in servizio alla dogmatica e sono assai ermetici in forma e linguaggio. Quelli più recenti danno una bibliografia aggionata e - quasi sempre - riportano i testi più significativi dei Padri. 